\title{
Orthopaedie van vandaag
}

Citation for published version (APA):

van der Linden, A. J. S. (1982). Orthopaedie van vandaag. Rijksuniversiteit Limburg. https://doi.org/10.26481/spe.19820319al

Document status and date:

Published: 19/03/1982

DOI:

10.26481/spe.19820319al

Document Version:

Publisher's PDF, also known as Version of record

\section{Please check the document version of this publication:}

- A submitted manuscript is the version of the article upon submission and before peer-review. There can be important differences between the submitted version and the official published version of record.

People interested in the research are advised to contact the author for the final version of the publication, or visit the DOI to the publisher's website.

- The final author version and the galley proof are versions of the publication after peer review.

- The final published version features the final layout of the paper including the volume, issue and page numbers.

Link to publication

\footnotetext{
General rights rights.

- You may freely distribute the URL identifying the publication in the public portal. please follow below link for the End User Agreement:

www.umlib.nl/taverne-license

Take down policy

If you believe that this document breaches copyright please contact us at:

repository@maastrichtuniversity.nl

providing details and we will investigate your claim.
}

Copyright and moral rights for the publications made accessible in the public portal are retained by the authors and/or other copyright owners and it is a condition of accessing publications that users recognise and abide by the legal requirements associated with these

- Users may download and print one copy of any publication from the public portal for the purpose of private study or research.

- You may not further distribute the material or use it for any profit-making activity or commercial gain

If the publication is distributed under the terms of Article $25 \mathrm{fa}$ of the Dutch Copyright Act, indicated by the "Taverne" license above, 


\section{Orthopaedie van vandaag}

\section{REDE}

Uitgesproken bij de aanvaarding

van het ambt van gewoon hoogleraar in de Orthopaedie

aan de Rijksuniversiteit Limburg

op vrijdag 19 maart 1982

door

Dr. A. J. van der Linden 

Toen mijn opleider San Giorgi in 1962 als eerste in Nederland benoemd werd tot hoogleraar in de orthopaedie aan de Nijmeegse Universiteit, gebeurde dit op een moment dat de orthopaedie stond aan het begin van grote bloei en ontwikkeling.

Deze benoeming van San Giorgi was internationaal gezien zekergeen primeur, maar werd snel gevolgd door soortgelijke benoemingen aan andere universiteiten en kon er een begin gemaakt worden met de opbouw van een wetenschappelijk kader. Dit heeft er toe bijgedragen dat in Nederland aansluiting gevonden kon worden bij de snelle ontwikkeling van dit vakgebied in het buitenland en dat de Nederlandse orthopaedie zelf zich in toenemende mate internationaal heeft kunnen presenteren.

Het was dan ook verheugend dat de Rijksuniversiteit Limburg besloot tot het instellen van een leerstoel in de orthopaedie en voor mijzelf een genoegen hieraan inhoud te mogen geven en bij te dragen aan de verdere uitbouw van de faculteit.

De orthopaedie houdt zich bezig met de functie van het bewegingsapparaat, ofwel met preventie en behandeling van aangeboren, degeneratieve, infectieuze en traumatische afwijkingen aan botten, spieren en gewrichten. Ook de behandeling van goedaardige en kwaadaardige gezwellen aan deze lichaamsdelen behoort tot haar aandachtsgebied. Deze omschrijving wijst reeds op de samenhang met vele andere vakgebieden. Naast samenwerking met verschillende klinische disciplines is er ook een band met de psychologie en bepaalde vormen van sociale geneeskunde, zoals bedrijfs- en verzekeringsgeneeskunde, terwijl samenwerking met de huisarts vanzelfsprekend is.

Zoals vermeld heeft de orthopaedie een grote vlucht genomen. Deze groei is spectaculair geweest, vooral wat betreft de bio-mechanische aspecten. Een ieder is bekend met het bestaan van de endoprothesen; kunstgewrichten die in het menselijk lichaam worden ingebracht en waarvan het heup- en kniegewricht het meest bekend zijn. In principe kunnen veel verschillende gewrichten geheel of gedeeltelijk door endoprothesen vervangen worden, maar de successen met de heupprothese zijn door aard en ligging van het gewricht het meest overtuigend. Ook hier is het eindpunt nog niet in zicht en zijn verdere ontwikkelingen in volle gang. Ontwikkelingen die zowel betrekking hebben op de aard van het materiaal als op de fixatie in het lichaam. 
Toch zijn de reeds behaalde successen dusdanig dat menig patiënt ook in dit stadium op een gunstig verlopen operatie kan terug zien.

Een ander sterk in het oog lopende wooruitgang is geboekt bij de scoliosebehandeling. Het gaat hierbij om een verkromming van de wervelkolom die zeer ernstige vormen kan aannemen en vervorming van rug en borstkas geeft. Onbehandeld kan de scoliose op latere leeftijd zelfs ademhalingsproblemen geven. Was aanvankelijk alleen correctie mogelijk met behulp van uitwendige steun met gipsbedden en orthopaedische korsetten, later gevolgd door operatieve fixatie met botspanen uit been of bekken; thans zijn de mogelijkheden bijna sensationeel verbeterd door het aanbrengen van inwendige, metalen correctiemiddelen aan de voor- of achterkant van de wervelkolom. Deze scoliosebehandelingen zijn over het algemeen samengebracht in een aantal centra en we zijn gelukkig ook in Maastricht in de gelegenheid te zijn een dergelijke centrumfunctie te vervullen.

Het is niet de bedoeling hier een opsomming te geven van alle vorderingen die in de orthopaedie gemaakt zijn, maar eerder om stil te staan bij het vele werk dat ons nog te wachten staat. Hoe fraai en onmisbaar de resultaten van ons bio-mechanisch denken moge zijn en hoe gelukkig de resultaten ons ook stemmen, het maant eerder tot grote bescheidenheid dan tot overmatige trots. Al de beschreven hulpmiddelen treden corrigerend op bij de gevolgen van een bepaalde afwijking. De aard van deze afwijkingen is nog altijd goeddeels onbekend en zijn langs meer natuurlijke weg en met minder ingrijpende middelen nauwelijks te beïnvloeden. Fysiologisch en bio-chemisch onderzoek geeft ons hier en daar een fragmentarisch beeld van datgene dat bij een scoliose of degeneratieve gewrichtsafwijking gaande is, maar van een totaalbeeld zijn we nog ver verwijderd. Het onderzoek zal naast de verdere ontwikkeling van kunstmatige correctiemogelijkheden vooral gecentreerd moeten worden op de ziekte zelf. Daarnaast zal verbetering van transplantatiemogelijkheden van bot, kraakbeen en peesweefsel verder bestudeerd moeten worden, met als doel een gezonde integratie van donorweefsel in het lichaam van de patiënt. Het is om vele redenen geen eenvoudige opdracht voor de Nederlandse orthopaedie om zich te verdiepen in de basisresearch, maar het lijkt mij gezien de verantwoordelijkheid die de orthopaed draagt bij de behandeling van degeneratieve afwijkingen een onontkoombare opdracht en een gebundelde krachtsinspanning meer dan waard.

De biologische en mechanische aspecten van de orthopaedie moge voor ieder duidelijk zijn, de psycho-sociale aspecten lijken nauwelijks 
van minder belang. Dat is zeker niet uniek voor de orthopaedie en geldt voor ieder medisch vakgebied. Het is bekend dat de psyche invloed heeft op het lichaam en ziekteverschijnselen kan geven. dat lijkt bijna vanzelfsprekend, wanneer men bedenkt dat onze hersenen een deel van ons lichaam zijn en lichaam en psyche binnen een geheel functioneren. Hevige of langdurige psychische gebeurtenissen, die in de buitenwereld haar oorsprong vinden, kunnen lichamelijke gevolgen hebben. Hevige of langdurige lichamelijke problemen, zoals pijn, beinvloeden de psyche. In dat verband zou ik enige kanttekeningen willen maken bij de lage rugpijn.

Het aantal klachten over rugpijn is sterk toegenomen, toch wordt in een aantal gevallen geen overtuigende oorzaak hiervoor gevonden. Ook valt niet aan te nemen dat het aantal degeneratieve afwijkingen relatief is toegenomen. Hiervan uitgaande is het niet verwonderlijk dat ook andere vakgebieden zich voor dit braakliggend terrein zijn gaan interesseren. Voor de toename van pijnklachten in het algemeen, en dus ook van rugpijn, zijn heel wat redenen te bedenken.

Om enige veel gehoorde te noemen:

- De moderne mens is verwend en verdraagt minder ongerief.

- Door de vele automatismen in ons werk treedt eenzijdige lichamelijke belasting op.

- De samenleving kent voor veel mensen veel onaangename kanten en men grijpt de gelegenheid zich daaraan te onttrekken.

- Ons levenspatroon is onevenwichtig met hollen en stilstaan. De hele dag kantoor en "s avonds of in het week-end intensieve sport. $\mathrm{Er}$ is een grote reeks van mogelijkheden te bedenken en we kunnen daarbij alle bijzonderheden in onze levenswijze de revue laten passeren. In individuelle gevallen verklaart dat over het algemeen weinig en een feit is dat de orthopaed dikwijls geen relatie vindt tussen de klachten en de bevindingen bij zijn onderzoek. Dat is op zichzelf geen reden om aan te nemen dat de klachten psycho-somatisch van oorsprong zijn en menig patiënt voelt zich mogelijk terecht door suggesties in die richting in de kou gezet. Men moet ervan uitgaan dat in het algemeen gesproken iedere patiènt die over pijn klaagt die pijn ook voelt. Het is de mate van klachten in verhouding tot de vaak geringe afwijkingen die de orthopaed onzeker maakt. Daarom is het niet verwonderlijk dat de orthopaed behoefte heeft aan hulp wan de kant van de klinisch psycholoog. Hierbij dreigt evenwel het gevaar van een onevenwichtige benadering. Lage rugpijn is een vrij algemeen verschijnsel en het is verleidelijk deze vorm van pijn te isoleren en als een specifiek sociaal-psychologisch probleem te behandelen. Hierbij vergeet men gemakkelijk dat soortgelijke problemen zich ook op 
andere gebieden voordoen. Er zijn veel niet verklaarde klachten over hoofdpijn, bukpüin, pijn op de borst, etc., die ook in aanmerking komen woor een sociaal-psychologische visie. Het lijkt echter primair een taak van de klinisch psycholoog zich bezig te houden met het probleem pijn, zoals b. $v$. een orthopaed zich bezighoudt met degeneratieve gewrichtsafwijkingen. De verschillende gewrichten vragen hierbij wel om een afzonderlijke therapeutische benadering, maar de arthrosis is bij ieder gewricht gelijk en hier dient verder onderzoek ook op gericht te zijn. Zo hebben psychologen en epidemiologen zich met grote ijver op de lage rugpijnpatient geworpen, $m$.i. niet vanuit een overtuigende visie op het gegeven pijn, maar vanuit een geïsoleerde vraagstelling bij mensen met lage rugklachten. De orthopaed ziet graag een ondersteuning van de psycholoog bij hulp aan de lage rugpijnpatiènt, maar dan wel gedragen door een meer algemene visie op pijn. Lage rugklachten dreigen anders steeds meer in een afzonderlijke positie terecht te komen, waardoor niet te verwachten valt dat een oplossing in het verschiet ligt. De vraag aan de psycholoog betreft de wijze waarop de patiënt de pijn verwerkt. Tevens vragen we hem mee te helpen inzicht te krijgen in het mechanisme dat de patiënt steeds naar de arts voert met klachten waarvan in alle redelijkheid verondersteld mag worden dat het om dragelijke klachten gaat en waarvoor de arts klaarblijkelijk geen enkel soelaas biedt. Een aantal patiënten lijkt bestaande pijn of pijn die hooit bestaan heeft slecht te verwerken. Onder slechte verwerking zou ik willen verstaan het onvoldoende distantie kunnen nemen van de pijn, waardoor op zichzelf goed houdbare klachten een te centrale plaats in zijn denkwereld gaan innemen. De presentatie van de pijn zal een uiting zijn van deze beleving en kan een volslagen verkeerde indruk geven van mate en intensiteit. Deze presentatie kan er bewust op gericht zijn dit verkeerde beeld te scheppen, maar kan ook verhevigd worden door angstgevoelens of andere bijkomende zaken. Een presentatie die niet in overeenstemming is met de lichamelijke werkelijkheid, houdt ook het gevaar in van overtreatment. Een behandeling die zijn doel voorbijschiet en de moeilijkheden niet oplost.

Een goed voorbeeld van het grote belang van het juist taxeren van de pijnbeleving bij de behandeling van de patient is de spondylodese. De wervelkolom bestaat uit een aantal elementen (wervellichamen) die bewegelijk met elkaar verbonden zijn. Zolang die beweeglijkheid zich binnen bepaalde grenzen afspeelt is er voldoende stabiliteit om een soepel verloop van de mobiliteit mogelijk te maken. Zodra deze grenzen overschreden worden, kunnen pijnlijke weefselreacties optreden die ons een normaal functioneren beletten. Het is op zichzelf 
niet altijd eenvoudig om een dergelijke instabiliteit aan te tonen. Een

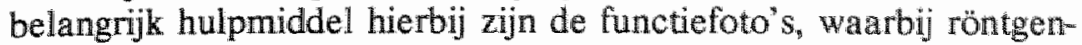
opnamen gemaakt worden in gebogen en gestrekte houding en de onderlinge verhouding van de wervels bezien kan worden. Treedt een verschuiving op van twee aangrenzende wervels in voor- achterwaartse richting dan spreekt men van instabiliteit. Bij een lage rugpijnpatiënt met aantoonbare instabiliteit lijkt een spondylodese voor de hand te liggen. Bij een spondylodese wordt gebruik gemaakt van bottransplantaat dat een benige verbinding moet gaan vormen tussen de instabiele wervels om aldus tot stabiliteit te komen. Hoe vanzelfsprekend de indicatie tot operatie lijkt; hoe hoog de verwachtingen soms zijn, de uitkomst van de operatie is vrij onvoorspelbaar. Soms slaat het bottransplantaat goed aan en ontstaat die benige consolidatie, maar heeft de patiënt nog steeds klachten. Soms treedt geen consolidatie op en moet de operatie als niet geslaagd beschouwd worden, maar is de patiënt wel klachtenvrij. Volledigheidshalve wil ik opmerken dat andere technieken hier wel enige verbetering in gebracht hebben, maar de indicatiestelling blijft bij deze operatie nog steeds een van de grootste knelpunten.

Er zijn verschillende operatietechnieken bekend, maar de zeer uitgebreide literatuur overziende, maakt de gevolgde techniek geen overwegend verschil uit. Het zal U dan ook niet verbazen dat menig orthopaed zich vragen stelt over de zuiverheid van zijn indicatiestelling. Het reactiepatroon van de patiënt op pijn lijkt een belangrijk gegeven en de hulp van de psycholoog hierbij geboden. Het gevaar dat chronische pijn een eigen leven is gaan leiden is niet denkbeeldig en daarom bij lage rugpijn voorhanden. In dat geval zal zelfs de meest geslaagde operatie weinig succes hebben en er zijn aanwijzingen dat de psycholoog kan bijdragen aan een betrouwbaarder indicatiestelling bij de hierboven beschreven rugoperaties. Hiertoe is nog veel research en vooral prospectief onderzoek nodig, waarvoor behalve de capaciteitsgroep psychologie van de faculteit ook de klinische psychologie van het ziekenhuis belangstelling getoond heeft.

Het feit dat de oorzaak van lage rugpijn in een aantal gevallen niet duidelijk is heeft verregaande consequenties. Het werkverzuim op grond van lage rugklachten is groot en het is niet eenvoudig te bepalen in hoeverre dat terecht is. In de loop van de jaren is men tot de overtuiging gekomen dat niet ieder teken van degeneratie dat zichtbaar is op de röntgenfoto gezien moet worden als een basis van lage rugklachten. De problemen doen zich reeds voor bij een aanstellingskeuring, waarbij het gaat om een arbeidsgeschiktheid op lange 
termijn. Verder bij ziektemeldingen, waarbij arbeidsgeschiktheid op korte termijn in het geding is. Omdat bij een aanstellingskeuring meer de nadruk valt op de prognose zal men hier grotere betekenis hechten aan de röntgenfoto. De hiermee geconstateerde degeneratieve afwijkingen hoeven geen klachten te geven, maar kunnen dat in de toekomst wel gaan doen. Bij keuring voor periodieke arbeidsongeschiktheid, wordt grotere waarde gehecht aan het klinisch onderzoek en in het bijzonder aan de beweeglijkheid van de wervelkolom omdat hiermee een indruk gekregen wordt van de klachten van het moment. Zo adviseerde San Giorgi in 1963 bij een keuring voor militaire dienst of bij aanstelling voor het bedrijfsleven, in ieder geval een röntgenologisch onderzoek van het onderste deel van de wervelkolom te verrichten.

Over de betekenis van röntgenfoto's bij lage rugklachten zijn veel tegenstrijdige publicaties verschenen en zo ontstond in Maastricht de behoefte aan onderzoek op grond van eigen ervaringen. Enkele jaren terug is op onze afdeling bij 500 patiënten met lage rugklachten een na-onderzoek verricht op grond van röntgenafwijkingen, leeftijd, beweeglijkheid van de wervelkolom en de arbeid die door de betreffende patient verricht werd. Ter vergelijking gebeurde hetzelfde bij 100 klachtenvrije personen.

Beperken we ons vandaag tot twee veel voorkomende degeneratieve afwijkingen van de wervelkolom: spondylosis en discopathie. Spondylosis is een afwijking waarbij men op de röntgenfoto haakvormige veranderingen ziet ontstaan aan de wervellichamen. Door de meeste onderzoekers wordt weinig waarde gehecht aan dit verschijnsel en in ons onderzoek zagen we zelfs een hoger percentage aan spondylosis in de klachtenvrije groep dan in de groep met klachten. Een discopathie is een versmalling van de kraakbeenschijf die twee wervellichamen met elkaar verbindt en het percentage discopathiëen blijkt bij ons onderzoek in de groep met rugklachten duidelijk groter.

De oorzaak van de rugklachten bij een versmalde discus is waarschijnlijk primair van mechanische aard, doordat deze versmalling een verhoogde druk geeft in de gewrichtjes van de wervelkolom op het betreffende niveau met degeneratie wan het gewrichtskraakbeen. Deze kraakbeendegeneratie heet arthrosis en wordt soms slijtage genoemd. Een dergelijke arthrosis kan een wisselende mate van klachten geven, met lange klachtenvrije perioden. Het verschijnsel kan voorkomen in ieder gewricht, maar door de diepe ligging van de wervelkolomge wrichtjes laat het fenomeen zich hier moeilijker observeren dan bijwoorbeeld in het meer oppervlakkig gelegen knie- 
gewricht. Daarom stel ik voor onze aandacht voor een moment te verplaatsen naar de knie.

Bij het kniegewricht zien we dat arthrosis soms jaren rustig verloopt, zelfs bij intensief gebruik, om dan plotseling pijn te geven met zwelling door vochtophoping. De pijn wordt wel verklaard door het feit dat bij arthrosis kraakbeenstukjes loslaten die zich vrij door het gewricht bewegen tot zij zich vastzetten aan het binnenste gewrichtskapsel dat dan reageert met een verhoogde pijnlijke vochtproductie. Dit alles is een vereenvoudigde weergave van de feiten en vraagt om enige aanvulling. Bio-chemische factoren, ook vanuit het kraakbeen spelen hier waarschijnlijk een rol. Hierbij wil ik refereren aan hetgeen bij een voetbalknie plaatsvindt. Onder een voetbalknie verstaan we het inscheuren van de meniscus. De meniscus is een langwerpig kraakbeenschijfje aan de rand van het kniegewricht dat ter plaatse de ruimte opvult die ontstaat doordat een bolvormig gewrichtsoppervlak op een plat gewrichtsoppervlak rust. De meniscus dient niet slechts voor het opvullen van een vrije ruimte, maar heeft als voornaamste taak de spreiding van de belasting over een groter oppervlak. Welnu als deze meniscus overlangs inscheurt en het losse deel netjes op zijn plaats blijft liggen geeft het letsel weinig bezwaren. Schuift dit losse deel tussen de afsteunende gewrichtsvlakken dan zit de knie op slot. Dit slotverschijnsel gaat vaak gepaard met verhoogde vochtproductie van het gewrichtskapsel. Bij operatieve verwijdering van de defecte meniscus wordt dan in veel gevallen geen of nauwelijks een kraakbeenletsel van het gewrichtsoppervlak aangetroffen en is geen sprake van direct contact van losse delen met het kapsel. Het is niet ondenkbaar dat de vochtsecretie een gevolg is van het vrijkomen van chemische producten uit het kraakbeen die het kapsel tot deze vochtproductie aanzetten.

Terugkerend naar de rug, waar we bezig zijn met de bespreking van de arthrosis van de wervelkolomgewrichtjes bij versmalling van de tussenwervelschijven, hoop ik U duidelijk gemaakt te hebben dat het hier gaat om een afwijking die zowel klachten geven kan als klachtenvrij verlopen kan. Hoe dat mechanisme verloopt is niet precies verklaarbaar, maar voor de praktijk niet altijd van belang. Het gaat er niet altijd om of er afwijkingen gevonden worden, maar of die afwijkingen klachten geven. Om een indruk te krijgen van de pijn is het gewone lichamelijke onderzoek nog steeds onmisbaar. Een arthrosis in een klinisch actief stadium geeft een pijnlijke functiebeperking van het betreffende gewricht en op dit gegeven is ons rugonderzoek hier grotendeels gebaseerd. Ontbreekt enige vorm van functieverlies, dan lijkt het onwaarschijnlijk dat op het moment van onderzoek de pijn- 
klachten ernstig van aard zijn en gunstig zullen reageren op medische behandeling. Ook de sociale wetgeving lijkt bij werkverzuim dan nauwelijks van toepassing te zijn. Wel is het denkbaar dat de gevonden afwijking in de toekomst klachten gaat geven en dit zal nu bij een aanstellingskeuring bij voor de rug belastende arbeid van belang kunnen zijn. Uit ons eigen onderzoek bleken mensen uit de klachtenvrije groep, maar met röntgenologisch aantoonbare discopathiëen een goede rugfunctie te hebben. Benadrukt moet worden dat bij verschillende andere rugafwijkingen niet dezelfde verklaring gegeven kan worden voor eventuele functiebeperking. De moeilijkheid blijft dat de arts geen relevante afwijkingen vindt en de patiënt klachten heeft. Afgaande op mijn ervaringen bij keuringen, vooral voor de Raad van Beroep, blijkt dat voor het rechtsgevoel van de betrokkenen soms hoogst onbevredigend te zijn. Het geven van ziekte-inzicht is hierbij van het grootste belang en zal niet tot een enkele uitleg beperkt kunnen blijven. Soms moet er ook begeleiding gegeven worden. Ten aanzien van die begeleiding zij opgemerkt dat de taak van de arts primair een adviserende is en hij niemand dwingend iets opleggen kan. Ieder medisch advies kan en mag genegeerd worden. $\mathrm{Zo}$ is dat ook met arbeid als medisch advies. Het is waarschijnlijk een van de meest genegeerde adviezen en dat is op zichzelf al een interessant gegeven. Men vraagt zich af of bij arbeidsverzuim niet in teveel gevallen een medische oorzaak gezien wordt. De vraag komt naar voren of de arts alleen voldoende in staat is de patiënt te overtuigen van de lichamelijke onschuld van zijn klachten en de psycholoog hierbij niet in grotere mate behulpzaam moet zijn.

Aan het eind van dit onderwerp hoop ik dat $U$ mij toestaat om aan de hand van enkele getallen aan te geven dat de behandelingsproblematiek van de lage rugpijnpatiënt voor de orthopaed ook weer niet zodanig is dat enige zin aan de behandeling ontbreekt. Hierbij moet worden opgemerkt dat bij afwezigheid van orthopaedische afwijkingen van onze kant geen therapeutische maatregelen genomen werden. Het ging bij veel klachten om onschuldige aandoeningen zoals passagière spierontsteking, platvoeten, verzwakte buikspieren (b.v. na een zwangerschap), surmenageklachten, die allemaal goed reageren op eenvoudige maatregelen. Diverse aandoeningen luisteren goed naar medicamenten of fysiotherapie.

Van de 500 door ons nagetrokken patiënten waaronder het merendeel mannen, waren ruim meer dan de helft tevreden met de behandeling. Bijna 100 patiënten werden terug verwezen naar de huisarts of uit de behandeling ontslagen, omdat gemeend werd dat de klachten niet op orthopaedisch terrein lagen. Slechts enkelen werden rechtstreeks 
naar een andere specialist verwezen, zoals naar de neuroloog bij verdenking op b.v. een hernia. Ruim 100 patënten zujin niet teruggekomen, merendeels zonder noemenswaardige afwijkingen. Van de 500 patiënten werden er slechts drie geopereerd.

Een geheel ander onderwerp dat mij ter harte gaat, is de operatieve behandeling van reumatoide arthritis. $\mathrm{Bij}$ de reumatoide arthritis gaat het wat de gewrichten betreft om een specifieke ontstekingsreactie van het gewrichtskapsel waarbij woekerend kapselweefsel thet gewrichtskraakbeen aantast. In eerste instantie zullen deze verschijnselen door de reumatoloog bestreden worden, maar soms moet operatief ingegrepen worden en het binnenkapsel verwijderd worden. Een dergelijke ingreep kan alleen gebeuren als het gewricht nog redelijk intact is. Men hoeft zich geen illusies te maken dat een operatieve ingreep iets te maken heeft met reuma-bestrijding. ook nu is de oorzaak onbekend, maar kapselverwijdering kan het aangetaste gewricht wel voor soms lange tijd tot rust brengen, zodat gedurende deze periode verdere destructie achterwege blijft. Blijvende behandeling door de reumatoloog kan hierbij niet gemist worden.

Bij sterke aantasting van het gewricht had men in vroegere dagen als belangrijkste mogelijkheid het vastzetten van het gewricht, maar ook hier heeft het inbrengen van een prothese goede resultaten gegeven. Vooral bij aandoeningen van de handen is het van belang dat niet te lang gewacht wordt met operatief ingrijpen. Takken van belangrijke zenuwen als de nervus medianus en nervus ulnaris verzorgen de handspieren en bij langer bestaande reuma in pols en handgebied raakt door verhoogde druk op vooral de nervus medianus de verzorging van handspieren in de knel. Het vrijleggen van deze zenuw is een weinig ingrijpende operatie en is een van de voorwaarde voor een goede handfunctie. Het plaatsen van prothesen in de handgewrichten heeft niet altijd het resultaat gegeven dat men ervan verwacht heeft. Het kosmetisch effect is vaak beter dan het functionele. Andere, meer conservatieve operatiemogelijkheden van de handgewrichten geven vaak beter functioneel resultaat.

Voorop staat een goede samenwerking met de reumatoloog en in sommige klinieken loopt deze samenwerking uitstekend, waarbij ook gezamenlijk polikliniek gedaan wordt. Er zijn klinieken waar deze samenwerking minder goed verloopt, maar hierbij gaat het nooit om competentiekwesties, maar is alleen sprake van een te geisoleerde praktijkvoering. Samenwerking tussen reumatoloog en chirurg is bij operatieve behandeling een absoluut gegeven en gelukkig is bij alle veranderingen in ons ziekenhuis de bestaande goede samenwerking 
tussen beide afdelingen ook voor de toekomst verzekerd.

Zo heeft ook een soortgelijke samenwerking die er bestaat met vooral het team van het kinderrevalidatiecentrum in Valkenburg mij steeds sterker overtuigd van de noodzaak van multidisciplinaire benadering van veel problemen en de nadelen van veelsoortige geisoleerde behandelingen. Dat is het intrappen van een open deur, behalve in de praktijk. Zeker bij neurologische aandoeningen is naast een goede operatietechniek wooral een goed overleg van belang om het type en het moment van een operatie te bepalen. Vooral een goede samenwerking met de revalidatie-arts, met zijn meer intensieve kontakten met bepaalde kategoriëen patiënten en zijn centrale plaats in het revalidatiecentrum, is onmisbaar.

Het is reeds meer dan $2 \frac{1}{2}$ jaar geleden dat mijn benoeming aan de faculteit van kracht werd. Met deze openbare les ben ik dus zeker niet te vroeg. We hebben het in dit opzicht ook niet gemakkelijk in Maastricht. In ons onderwijssysteem is geen plaats voor het geven van colleges en er is een zekere ambivalentie t.a.v. de inaugurale rede. Aan de ene kant is het vreemd aan ons systeem. Aan de andere kant is het ook in dit instituut, waar kennis langs de weg van zelfwerkzaamheid verkregen moet worden en de docent vooral een adviserende en begeleidende taak heeft, een goede zaak zich zelf voor te stellen. Ik heb geprobeerd $U$ een beeld te geven van de wijze waarop de orthopaedie vandaag functioneert. Op mijn afscheidscollege zult $U$ dan kunnen vernemen wat de toekomst van vandaag is. Ik zie die toekomst met aktief vertrouwen tegemoet. Vertrouwen dat we ook nodig hebben als we denken aan de moeilijkheden van nu. Onze belangrijkste moeilijkheid spitst zich toe op de landelijke verhouding tussen algemene heelkunde en orthopaedie. Op dit niveau verloopt de relatie tussen beide groepen vrij stroef. Gelukkig stoort niet iedereen zich aan het beleid van officiële organen en werken centrale meningsverschillen niet onmiddellijk door naar locale arbeidsverhoudingen. Ook in Maastricht gaan we onverstoorbaar verder met in vele opzichten een voortreffelijke verstandhouding tussen beide afdelingen. Toch dreigt ons een klein maatschappelijk drama dat niet onder de tafel geschoven kan worden en na meer dan 80 jaar om een oplossing begint te vragen. Deze oplossing wordt noodzakelijk door het verzadigd raken van de arbeidsmarkt voor specialisten. Om de controverse op geen enkele wijze te verscherpen beperk ik mij tot het aangeven van het probleem. Algemene heelkunde is een breed specialisme waarvan een aantal deelspecialismen zich hebben afgesplitst, maar waarbij de algemeen chirurg werkzaam is gebleven op diverse terreinen van deze deelspecialismen. Dergelijke overlappin- 
gen vinden trouwens ook plaats bij deelspecialismen onderling en binnen de bestaande opvattingen in Nederland is dat gerechtvaardigd en treft niemand enige blaam. Tussen chirurgen en orthopaeden gaat het om een nogal groot gemeenschappelijk gebied, n.l. fracturen en andere traumatische letsels aan het bewegingsapparaat.

De orthopaedie houdt zich, zoals gezegd, bezig met stoornissen aan het bewegingsapparaat en er zijn geen argumenten te bedenken daar de traumatische letsels niet toe te rekenen. In een aantal landen, waaronder de Verenigde Staten, Engeland en Scandinavische landen heeft men hieruit conclusies getrokken en is men gekomen tot een eenvoudige werkverdeling, waarbij de orthopaed alle letsels aan het bewegingsapparaat behandeld en de algemeen chirurg de letsels aan de inwendige organen en de bloedvaten. Bij grote traumata's werken zij samen, zoals dat ook gebeurt met andere specialismen. Hier in Nederland bestaat die samenwerking tussen chirurgen en orthopaeden ook, maar zonder tot een duidelijke werkverdeling te komen.

Ook in andere landen heeft dat probleem gespeeld, maar vooral in Engeland waar men de afgelopen eeuw met onnoemlijk veel oorlogsslachtoffers te maken gehad heeft, had zich reeds na de eerste wereldoorlog bij terugkerende legerchirurgen de overtuiging ontwikkeld dat chirurgische behandeling aan het bewegingsapparaat een ander karakter heeft dan wat men gewoonlijk aanduidt met weke delen chirurgie. Zo ontstond een natuurlijke selectie waarbij de algemeen chirurg zich distantiëerde van de chirurgie aan de harde delen. In andere landen werd dat proces bevorderd door regulerend optreden van verzekeringsorganen en ook in Nederland hebben we een dergelijke ontwikkeling gekend. In de na-oorlogse jaren zag de Sociale Verzekeringsbank nawwlettend toe op de behandeling van bedrijfsongevallen zodat de orthopaedische afdeling van het Wilhelmina Ziekenhuis in Amsterdam onder leiding van Prof. Verbeek zich ontwikkelen kon tot een behandelingscentrum van niet genezen fracturen, pseudarthrosen genaamd. Later bij het tot standkomen van de algemene ziektewet, die een gedeelte van de taak van de Socialle Verzekeringsbank overnam, is deze actieve externe participatie in dit deel van de gezondheidsorg weer verdwenen en de curatieve sector weer geheel de vrije hand gegeven.

In Maastricht, als op vele andere plaatsen, hebben goede persoonlijke verhoudingen ervoor gezorgd dat deze onduidelijke grenzen tussen de verschillende vakgebieden geen onoverkomelijke problemen gegeven hebben, maar het zou naief zijn te menen dat men dergelijke kwesties kan overlaten aan toevallig, plaatselijke schakeringen aan ambities of aan persoonlijke verhoudingen. Komt een taakstelling in goed overleg 
en op vrijwillige basis niet op landelijk niveau tot stand, dan zal een takenpakket vroeg of laat door anderen worden afgedwongen. Het zou niet verbazen als een opgelegde regeling met minder begrip tot stand kwam, dan veel chirurgen en orthopaeden tot op dit moment voor ellkar kunnen opbrengen. Een goede taakverdeling wordt urgent omdat twee verschillende groepen zich gedeeltelijk eenzelfde arbeidsterrein toedenken en hun potentiëel via opleidingen daarop richten. Er komen dus teveel chirurgen en orthopaeden en waar dat in de gezondheidszorg toe leiden kan behoeft geen nadere toelichting.

Wanneer gesproken wordt over de traumatologie dan is bijzondere aandacht voor de sporttraumatologie op haar plaats. Het is goed er nogmaals op te wijzen dat de sporttraumatologie slechts een onderdeel is van de sportgeneeskunde. De sportgeneeskunde houdt zich bezig met de reactie van het menselijk lichaam op de sportbeoefening, waar vooral fysiologen bij betrokken zijn. De sporttraumatologie heeft een aanmerkelijk beperkter aandachtveld en houdt zich bezig met schade die wordt toegebracht aan het bewegingsapparaat als gevolg van sportbeoefening. Op vele plaatsen zijn afzonderlijke polikliniekuren voor sporttraumatologie ingesteld, waardoor de indruk ontstaat of de geneeskunde een afzonderlijk arsenaal aan diagnostische en therapeutische mogelijkheden achter de hand gehouden heeft voor sportmensen. Niets is minder waar uiteraard. Het zou menigeen een onbehaaglijk gevoel geven wanneer geavanceerde technieken of zeer bijzondere aandacht voor speciale bevolkingsgroepen gereserveerd zouden blijven en dat gebeurt ook niet. Toch verdient de sporttraumatologie een aparte plaats in ons denken, omdat bepaalde blessures veelvuldig bij sporters voorkomen. Ik doel hierbij in het bijzonder op surmenageletsels, waarvan de tennisarm, de liesblessure bij voetballers en de pijnlijke Achillespees bij atleten wellicht de meest bekendle zijn. Het gaat hier om schadelijke gevolgen van intensieve lichaamsbewegingen op bepaalde lichaamsdelen die niet ernstig zijn, maar de sportbeoefening belemmeren en in een aantal gevallen zelfs ziekteverzuim geven. De behandeling van dit soort letsels vraagt gewoonlijk veel geduld, maar is in wezen voor alle mensen gelijk en de letsels kunnen evenzeer opgelopen worden buiten het sportgebeuren om, in het normale leven van alledag. Alleen de frequentie van een aantall van deze surmenageklachten ligt in de sportwereld hoger en vraagt dan ook vooral vanuit het oogpunt van preventie onze speciale aandacht. Een dergelijke preventie zou ook een rol kunnen spelen bij het voorkomen van degeneratieve gewrichtsafwijkingen. Uit een Maastrichts onderzoek is gebleken dat zeer intensieve beofening van 
de voetbalsport op latere leeftijd grotere kans op knie- en enkelklachten geeft dan normaal het geval is. Een goede geneeskundige begeleiding van de sportmensen door speciaal opgeleide artsen is dan ook niet alleen wenselijk voor de fysiologische aspekten van de sport, zoals het op de juiste wijze aankweken van snelheid, kracht en uithoudingsvermogen, maar is ook wenselijk ter voorkoming van genoemde letsels die veel sportgenoegen in de weg staan. Het is dan ook een wijs besluit geweest van de Vereniging voor Sportgeneeskunde om de opleiding van sportartsen te bevorderen. Het gaat hier om een gespecialiseerde opleiding met sterk fysiologische, maar ook klinische inslag waar onze orthopaedische afdeling gaarne aan meewerkt door gelegenheid te geven tot het lopen van stage. Hierbij mag niet verzwegen worden dat het vooralsnog geen eenvoudige taak lijkt voor deze specifieke sportartsen om hun weg te vinden binnen de organisatiestructuren van onze sportwereld. Het zou juist zijn wanneer deze sportartsen door de specialistenregistratiecommissie als specialist werden erkend en binnen de sportorganisaties middelen gevonden zouden worden deze artsen in de sportwereld te integreren.

Wanneer we erkennen dat orthopaedie een belangrijke maatschappelijke functie heeft, mag een woord over het onderwijs en de plaats die de orthopaedie daarin behoort in te nemen hier niet ontbreken. Over het Maastrichtse onderwijssysteem is veel gezegd en geschreven en nu we daar enkele jaren mee bezig zijn lijkt dit systeem aan de verwachtingen te voldoen. Een zwak punt is tot dusver de evaluatie, maar ook hier vindt langzaam maar zeker uitkristalisatie plaats. Hiermee hangt samen dat het systeem hoge eisen stelt aan de individuele discipline van de student, die in wisselende mate aanwezig is. De faculteit heeft twee taken: onderwijs en onderzoek. Een belangrijk element in de basisfilosofie is versterking van het eerste echelon. Aangenomen mag worden dat het onderwijs door de opstellers van de basisfilosofie als een belangrijke brug naar versterking van het eerste echelon gezien is. Een gedachtenbepaling hoe dat eerste echelon versterkt zou kunnen worden is dus een eerste vereiste. Deze versterking zou men in twee elementen kunnen opsplitsen. Op de eerste plaats een versterking van het eerste echelon vanuit zichzelf door bundeling van krachten die daar reeds aanwezig zijn. Bundeling van huisartsenpraktijken in wijkcentra, waarbinnen ook andere vormen van hulpverlening zoals geestelijke, maatschappelijke en preventieve zorg met elkaar in nauwer contact kunnen komen. Dat is niet gering en houdt een fundamentele verandering in van de gezondheidszorgstructuur zoals b.v. huisartsen in loondienst. Een 
tweede element is het naar buiten brengen van intramurale zorg, dus ziekenhuiszorg verplaatsen naar thuiszorg. Dat kan op twee manieren gebeuren en wel door de specialist buiten het ziekenhuis te laten functioneren en door de huisarts meer mogelijkheden te geven dan hij nu heeft. Als het ons ernst is met versterking van het eerste echelon dan denk ik dat de twee genoemde elementen onverbrekelijk met elkaar verbonden moeten $z$ inn. Bij het toenemend aantal specialisten en de verkleining van de huisartsenpraktijken dreigen we met zijn allen verloren te lopen, zonder werkelijke communicatie. Bij wijkcentra kan men met vaste consulenten vanuit het ziekenhuis werken en kunnen ook de huisartsen met aandachtsgebieden gaan werken, zoals dat nu binnen de verschillende klinische specialismen gebruikelijk is. Versterking van het eerste echelon zal overigens de technologische ontwikkeling binnen het ziekenthuis geen halt toeroepen, in zoverre lijkt de discussie rond de nieuwbouw van het Maastrichtse ziekenhuis ook weinig zinvol. Daarbij gaat het binnen onze samenleving om een heel andere zaak. Het gaat bij deze technologie niet om de vraag naar de beste vorm van gezondheidszorg, maar om de vraag wat onze gezondheid ons waard is.

Terugkerend op het onderwijs zal het $U$ bekend zijn dat de medische opleiding 6 jaar duurt. Bij een grotere omvang van de medische kennis is dat een jaar minder opleiding dan voorheen. Dat klinkt somberder dan het is want ook de verwachtingen zijn wat minder hoog gespannen. Was men vroeger na 7 jaar arts, dan was dat een kwalificatie die een levenslange optie gaf op het uitoefenen van de algemene praktijk. $\mathrm{Nu}$ is men na 6 jaar basisarts, d.W.z. een arts die een basis heeft om verder te gaan en een keuze mag maken uit de vele mogelijkheden voor een verdere opleiding, onder meer als huisarts. De medische studie moet dus de mogelijkheid geven een keuze te maken, niet alleen uit een van de vele vormen van praktische beroepsuitoefening, maar ook uit een van de basisvakken. Bovendien moet de opleiding de mogelijkheid bieden die voortgezette opleiding tot een goed einde te brengen. Een moeilijke opdracht, maar de enige opdracht die de faculteit ten aanzien van het onderwijs heeft.

Wat is de taak van de orthopaedie binnen dat onderwijs? Geen specifieke, wel een belangrijke, omdat gebleken is dat een zeer groot deel (men spreekt zelfs van meer dan de helft) van de klachten die bij de huisarts komen betrekking hebben op het bewegingsapparaat en een groot deel hiervan zal voor rekening van de orthopaedie komen. Het is voor de orthopaedie, net als voor ieder ander vakgebied, van levensbelang zich goed te presenteren aan de student. Het geeft de student keuzemogelijkheid en bovendien hebben alle vakgebieden een 
samenhang en kan geen enkel gebied binnen die wisselwerking gemist worden. Daar komt nog bij dat het Maastrichtse onderwijssysteen op deze samenhang gebaseerd is. Wanneer we zien hoe weinig rumte er bestaat binnen de studieduur van 6 jaar om in de praktijk kennis te maken met de verschillende vakgebieden, dan vraagt men zich af hoe vanuit het ziekenhuis met meer vrucht dan voorheen vaardigheden aan toekomstige huisartsen geleerd kan worden. Binnen die mogelijk heden neemt orthopaedie bovendien een verre van bevoorrechte plaats in, zeker niet wanneer men dat correleert aan de hoeveelheid klachten op dit terrein. Het komt er eigenlijk op neer dat binnen de bestaande situatie die kliniek nauwelijks mogelijkheden heeft om vanuit het onderwijs het eerste echelon te versterken. Besluit de basisarts huisarts te worden dan volgt een jaar gespecialiseerde opleiding, die zich vrijwel geheel buiten de kliniek afspeelt. Hierbij wordt stage gelopen bij huisartsen en dat ligt voor de hand, maar lijkt mij onvoldoende. Aangenomen mag worden dat wanneer langs deze weg voldoende vaardigheden verworven kunnen worden er nooit zoveel over versterking van het eerste echelon te doen geweest zou zijn. Het komt me voor dat klinici veel voor de opleiding van huisartsen kunnen betekenen, zoals ook blijkt bij nascholingscursussen. De orthopaedische afdeling is altijd bereid aan de huisartsenopleiding bij te dragen. Het zou misschien al veel helpen als deze opleiding met een jaar verlengd kon worden, zodat klinische stages gemakkelijker kunnen worden ingelast.

Wat het onderzoek betreft probeert de faculteit middelen te vinden om experimenten op gebied van gezondheidszorg in de eerste lijn van de grond te brengen. Een goed lopend experiment is het diagnostisch centrum, waarbij de huisarts gebruik kan maken van klinische hulpmiddelen zonder de patiënt naar een behandeld specialist te verwijzen. Dit experiment is toe te juichen, maar behoeft mogelijk enige aanvulling. Laat mij dit toelichten ten aanzien van de röntgendiagnostiek.

Het beschrijuen van röntgenfoto's door de röntgenoloog is van groot belang. Het ook zelf bekijken van de foto's door de behandelend arts is in de orthopaedie van niet minder belang. Wanneer men de patiënt kent krijgt het röntgenbeeld een andere inhoud dan wanneer men volstaat met het lezen van welk voortreffelijk röntgenverslag dan ook. Om verschillende redenen zal de röntgenfoto gewoonlijk niet door de huisarts zelf beoordeeld worden, zodat wanneer op grond van het röntgenverslag de huisarts behoefte heeft aan advies van de specialist, de een de patiënt gezien heeft en de ander de foto's. Dat zal niet altijd een vruchtbare discussie opleveren. Het ligt dan ook in de lijn het 
diagnostisch centrum uit te breiden met specialistische afspraakspreekuren, waar desgewenst huisarts en specialist samen de patiënt zien. Een nadeel is, en in strijd met de basisfilosofie, dat bij intensief gebruik hiervan, het eerste echelon zichzelf opheft, zodat ik primair voorstander blijf van wijkcentra met breed en gedifferentieerd opgeleide huisartsen, die in dat centrum consult ontvangen.

Aan het eind gekomen van deze oratie wil ik de traditie ook verder trouw blijven en ik doe dat met plezier. Het is een goede gewoonte een dankwoord te richten aan allen die hebben bijgedragen aan het eigen kennisniveau en de mogelijkheden te memoreren die men gekregen heeft die kennis te benutten. Hierbij beperk ik mij tot het specialistisch deel van mijn werk.

Mijn chirurgische vooropleiding ontving ik van Dr. van Puyvelde in Rotterdam. In een prettige, collegiale sfeer, waarin goed gewerkt kon worden en tegelijk ruimte bestond voor plezierige omgang met elkaar, heb ik mij kunnen voorbereiden op mijn orthopaedische toekomst. Hiervoor mijn oprechte dank.

De orthopaedische opleiding mocht ik ontvangen van Prof. San Giorgi in Nijmegen, die vooral een grote klinische reputatie genoot en de juiste man was de orthopaedische afdeling van het Radboud Ziekenhuis van de grond te brengen. Dat gebeurde met een enorme inzet en een grote intelligentie en niet zonder persoonlijke offers. Zijn groot klinisch inzicht en operatieve vaardigheden werden met geduld en grote belangeloosheid op zijn assistenten overgedragen en dat gebeurde in een sfeer die de juiste intensiteit had om optimaal te kunnen werken. Die sfeer bracht met zich mee dat zijn oudassistenten ook nu nog een vriendenkring vormen. Wat San Giorgi niet kon overdragen was een soort charisma dat hij had, een charisma dat voor een belangrijk deel gedragen werd door de oprechte belangstelling die hij voor mensen had.

Zoals vele klinische hoogleraren ben ook ik uit de zogenaamde periferie gerecruteerd. Ik had het genoegen dat deze periferie in mijn geval het ziekenhuis St. Annadal betrof. Een ziekenhuis dat het om voor de hand liggende redenen niet gemakkelijk gehad heeft in de achter ons liggende jaren, maar waar ik ondanks alle problemen altijd goed en met veel plezier mijn werk heb kunnen doen. Dat het werk altijd op vereist niveau is blijven doorgaan is geen geringe verdienste van veel mensen in alle geledingen. Het klimaat in het ziekenhuis is met de komst van veel nieuwe mensen geleidelijkaan veranderd. Dat is een gelukkige zaak, gezien de nieuwe taak waarvoor we staan. 
Wanneer straks het ziekenhuis St. Annadal, Academisch Ziekenhuis Maastricht geworden is zal ik zeker niet met weemoed, maar wel met genoegen terugkijken op een periode, waaraan ook vele goede kanten zaten. Een periode die ik maar voor een gedeelte heb meegemaakt, maar waarin dr. Naber ruim dertig jaar geleden als eerste orthopaed in Maastricht van start ging en de orthopaedie tot ontwikkeling bracht. Een ontwikkeling die niet mag blijven stilstaan en die ik in hechte samenwerking met vele anderen hoop helpen te bevorderen.

Zeker wil ik niet nalaten om tot slot mijn erkentelijkheid uit te spreken voor het vertrouwen dat door het College van Bestuur en door de medische faculteit van deze universiteit in mij gesteld is. Ik hoop dat dit vertrouwen waarneembare resultaten zal hebben.

Ik dank $\mathbb{U}$ voor $U w$ aandacht. 